\title{
ANALISIS FAKTOR YANG MEMENGARUHI SWASEMBADA BERAS DI INDONESIA TAHUN 2018
}

\author{
(Analysis of Factors that Affect Rice Self-Sufficiency in Indonesia 2018) \\ Fikron Tanazzul Ahsani' ${ }^{1}$, Dwi Ardian² \\ Mahasiswa Politeknik Statistika STIS ${ }^{1}$ (Peminatan SK tingkat IV) \\ Mahasiswa Politeknik Statistika STIS² (Peminatan SK tingkat IV) \\ Jl. Otto Iskandardinata No. 64C Jakarta Timur, 13330 \\ Email: 16.9138@stis.ac.id
}

\begin{abstract}
ABSTRAK
Swasembada beras merupakan isu nasional yang selalu menjadi perhatian besar pemerintah. Masalah beras selalu melibatkan antar-kementerian dan lembaga. Oleh karena itu, kajian mengenai hal ini harus juga menyeluruh dan bisa diaplikasikan dengan baik. Mulai dari penyediaan data, kemudian analisis data, terus kebijakannya tentu merupakan langkah yang harus didorong untuk terus disempurnakan. Penelitian ini berusaha mengkaji faktor-faktor apa saja yang memiliki pengaruh terhadap swasembada beras di Indonesia. Data yang digunakan merupakan data terbaru dan terbaik yang dihasilkan oleh BPS dan Kementerian pertanian pada 34 provinsi di Indonesia. Metode inferensia yang digunakan adalah regresi linier berganda untuk melihat variabel-variabel apa saja yang memiliki pengaruh signifikan terhadap swasembada beras. Penjelasan juga selanjutnya dilakukan secara deskriptif dengan cara memberikan gambaran berupa tabel dan grafik. Berdasarkan analisis yang dilakukan diperoleh kesimpulan bahwa variabel persentase rumah tangga petani padi, dan alokasi pupuk urea subsidi secara signifikan memengaruhi swasembada beras serta variabel harga jagung pipil tidak signifikan memengaruhi swasembada beras.
\end{abstract}

Kata kunci: swasembada beras, padi, regresi linier berganda

\section{ABSTRACT}

Rice self-sufficiency is a national issue and always get the government attention. It involves some ministries and institutions. Therefore, the study about that problem must be comprehensive and well implemented. Starting from the provision of data, then data analysis, and then the policies are certainly steps that must be encouraged to continue to be improved. This study attempts to examine what factors that affect on rice self-sufficiency in Indonesia. The data used is the latest and the best data produced by BPS and the Ministry of Agriculture in 34 provinces in Indonesia. The inferencing method used is linear regression to see what variables have a significant influence on rice self-sufficiency. Explanation is descriptively by giving an overview in the form of tables and graphs. Based on the analysis, it can be concluded that the percentage of rice farming households and subsidy allocation of urea fertilizer significantly affect rice self-sufficiency and the price of shelled corn does not significantly affect rice selfsufficiency.

Keywords: rice self-sufficiency, paddy, multiple linear regression

\section{PENDAHULUAN}

Swasembada pangan adalah isu nasional yang melibatkan lintas kementerian dan lembaga pemerintah. Tidak heran jika seringkali kita dapatkan kericuhan akibat kebijakan masalah pangan, mulai dari produksi, data, distribusi, harga, hingga impor. Pangan di Indonesia diwakili oleh beras yang menjadi makanan pokok hampir seluruh masyarakat Indonesia. Menurut data Badan Pusat Statistik (BPS) pada tahun 2018 rata-rata konsumsi beras penduduk Indonesia mencapai 111,58 $\mathrm{kg}$ per kapita per tahun menempatkan Indonesia sebagai negara dengan konsumsi beras tertinggi di dunia. Menurut data BPS, Indonesia tidak pernah berhenti melakukan impor beras, bahkan ratarata impor cenderung meningkat setiap tahunnya. 


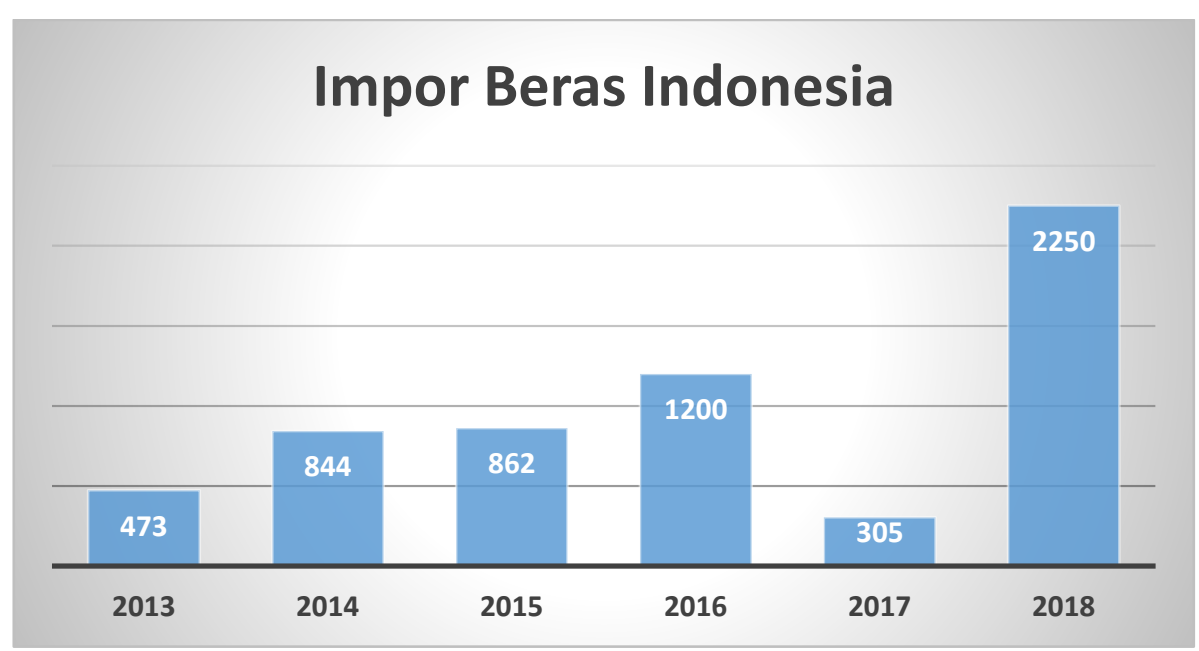

Sumber: Statistik Ekspor-Impor, BPS (2019)

Gambar 1. Data Impor Beras Indonesia (ribuan, ton)

Dari Gambar 1 diperoleh informasi bahwa Indonesia selalu melakukan impor beras dan cenderung mengalami peningkatan. Meski pada tahun 2017 sempat mengalami penurunan dengan hanya 305 ribu ton impor beras tetapi pada tahun 2018 kembali mengalami peningkatan yang sangat besar, yakni mencapai 2,25 juta ton. Data di atas tentu sesuatu yang mengkhawatirkan jika tidak segera dilakukan langkah yang tepat dalam rangka mengintervensi kebijakan sehingga swasembada beras benar-benar bisa diwujudkan. Dimulai dengan data yang valid, selanjutnya perlu dilakukan kajian. BPS telah melakukan terobosan baru untuk menghasilkan data beras yang kredibel dengan metode Kerangka Sampel Area (KSA). Dengan data tersebut perlu dilakukan kajian mendalam faktor yang memengaruhi swasembada beras, baik secara langsung maupun tidak langsung.

Pada tahun 2018 secara nasional, diperkirakan Indonesia surplus beras sebesar 2,8 juta ton menurut data KSA BPS. Data menghadirkan pertanyaan baru, apa memang harus impor. Langkah yang diambil pemerintah untuk melakukan impor beras dianggap sudah tepat karena kondisi di lapangan saat ini adalah distribusi beras tidak merata. Selain itu menurut survei yang pernah dilakukan oleh BPS juga (seperti survei stok beras di rumah tangga, di penggilingan, dII) diperkirakan bahwa stok beras kita tersebar 51.8 persen di rumah tangga, 12.21 persen di pedagang, 21.01 persen di Bulog, 8.88 persen di penggilingan, dan 6.1 persen di industri makanan dan minuman (horeka). Artinya, selain permasalahan produksi beras yang kecil juga karena distibusinya juga yang tidak proporsional (BPS, 2015).

Distribusi produksi beras antar-daerah juga terjadi ketimpangan yang cukup besar. Daerahdaerah yang padat penduduk seperti Jakarta, Banten, Sumatera Utara, Riau, dan lainnya mengalami defisit produksi beras yang parah. Hanya sebanyak 14 daerah atau tidak mencapai $50 \%$ yang surplus produksi beras, itu pun dengan surplus yang tidak besar.

\section{METODE}

Objek penelitian ini adalah 34 provinsi yang ada di Indonesia. Pendekatan dalam penelitian ini adalah pendekatan kuantitatif dengan data yang bersumber dari BPS dan Kementerian Pertanian. Data yang digunakan adalah data yang terakhir dirilis yakni pada tahun 2018. Data untuk variabel respons (dependen) berupa nilai swasembada beras, yang menunjukkan nilai positif dan nilai negatif. Positif berarti bisa dikatakan bisa memenuhi kebutuhan berasnya (swasembada), sebaliknya nilai negatif menunjukkan produksi beras belum memenuhi kebutuhan beras (tidak swasembada).

Berikut cara memperoleh nilai swasembada beras:

$$
S w_{i}=S_{i}-D_{i}
$$

Di mana: 
$S w_{i} \quad$ : Swasembada beras pada provinsi ke-i (ton)

$S_{i} \quad$ : Ketersediaan beras pada provinsi ke-i (ton)

$D_{i} \quad$ : Kebutuhan beras pada provinsi ke-i (ton)

Sedangkan cara memperoleh nilai kebutuhan beras:

$$
D_{i}=J P_{i} \times K_{i}
$$

Di mana:

$D_{i} \quad$ : Kebutuhan beras pada provinsi ke-i (ton)

$J P_{i} \quad$ : Jumlah penduduk pada provinsi ke-i (jiwa)

$K_{i} \quad$ : Rata-rata konsumsi beras per kapita pada provinsi ke-i dengan pendekatan ratarata konsumsi beras nasional (konversi dari $\mathrm{kg}$ ke ton)

Data-data yang diperoleh dari berbagai publikasi dan laporan kemudian disajikan dan dijelaskan secara deskriptif melalui grafik dan tabel. Metode analisis yang digunakan dalam penelitian ini adalah regresi linier berganda (multiple regression).

Variabel independen atau variabel bebas yang digunakan berupa harga jagung pipilan, persentase rumah tangga pertanian tanaman padi, dan alokasi pupuk urea bersubsidi. Sehingga, model regresi yang diterapkan dalam hal ini adalah sebagai berikut.

$$
Y=\beta_{0}+\beta_{1} X_{1}+\beta_{2} X_{2}+\beta_{3} X_{3}+\varepsilon
$$

Tabel 1. Deskripsi Variabel

\begin{tabular}{|l|c|l|c|}
\hline \multicolumn{1}{|c|}{ Variabel } & Simbol & \multicolumn{1}{|c|}{ Deskripsi } & Ekspektasi \\
\hline $\begin{array}{l}\text { Swasembada beras } \\
(\mathrm{Sw})\end{array}$ & $\mathrm{Y}$ & $\begin{array}{l}\text { Besarnya surplus/defisit beras berdasarkan } \\
\text { penghitungan kebutuhan konsumsi beras. }\end{array}$ & \\
\hline $\begin{array}{l}\text { Harga jagung } \\
\text { pipilan }\end{array}$ & $\mathrm{X}_{1}$ & $\begin{array}{l}\text { Merupakan harga jagung yang telah } \\
\text { melalui proses pemipilan. }\end{array}$ & $(+)$ \\
\hline $\begin{array}{l}\text { Persentase rumah } \\
\text { tangga pertanian } \\
\text { tanaman padi }\end{array}$ & $\mathrm{X}_{2}$ & $\begin{array}{l}\text { Merupakan perbandingan jumlah rumah } \\
\text { tangga pertanian tanaman padi terhadap } \\
\text { jumlah petani keseluruhan. }\end{array}$ & $(+)$ \\
\hline $\begin{array}{l}\text { Alokasi pupuk urea } \\
\text { bersubsidi }\end{array}$ & $\mathrm{X}_{3}$ & Merupakan & $(+)$ \\
\hline
\end{tabular}

Sebelum estimasi parameter model dilakukan, terlebih dahulu dilakukan pengujian asumsi normalitas. Asumsi normalitas harus dipenuhi dalam analisis regresi linier. Pemeriksaan asumsi normalitas dilakukan dengan menggunakan statistik uji Kolmogorov Smirnov. Pengujian apakah data berdistribusi normal atau tidak penting dilakukan karena analisis regresi mengharuskan data berdistribusi normal. Jika $p$-value yang didapatkan dari pengujian menggunakan statistik uji Kolmogorov Smirnov lebih besar dibanding taraf signifikansi yang digunakan (a), maka data berdistribusi normal dengan tingkat signifikansi sebesar a. Setelah asumsi normalitas dipenuhi, selanjutnya digunakan multiple regression untuk mengetahui variabel independen yang memiliki pengaruh signifikan terhadap variabel dependen.

Asumsi klasik yang selanjutnya harus terpenuhi adalah tidak boleh terdapat multikolinearitas dalam data. Multikolinearitas adalah kondisi terdapatnya hubungan linier atau korelasi yang tinggi antar-variabel bebas atau besar dalam model regresi. Pengujian asumsi ada atau tidaknya multikolinearitas menggunakan nilai VIF (variance inflation factor). Nilai VIF dalam hal ini didapatkan menggunakan bantuan dari software $R$-Studio. Jika VIF $>10$ untuk setiap variabel, maka terdapat gejala multikolinearitas. Jika $V I F \leq 10$, maka tidak terdapat gejala multikolinearitas pada variabel tersebut.

Selanjutnya, asumsi klasik yang diuji adalah tidak terdapat masalah heteroskedastisitas. Heteroskedastisitas adalah adanya ketidaksamaan varians dari residual untuk semua pengamatan pada model regresi. Prasyarat yang harus dipenuhi dalam model regresi adalah tidak adanya gejala heteroskedastisitas (atau homoskedastisitas). Statistik uji yang digunakan dalam pengujian asumsi homoskedastisitas ini adalah uji Breusch-Pagan. Jika $p$-value yang didapatkan dari 
pengujian menggunakan statistik uji Breusch-Pagan lebih besar dibanding taraf signifikansi yang digunakan (a), maka berarti tidak terdapat masalah heteroskedastisitas pada data (data sudah memenuhi asumsi homoskedastisitas) dengan tingkat signifikansi sebesar a.

Setelah semua asumsi klasik untuk regresi linier berganda berhasil dipenuhi, selanjutnya dilakukan uji signifikansi parameter. Uji statistik t pada dasarnya menunjukkan seberapa jauh pengaruh satu variabel independen secara individual dalam menerangkan variabel dependen. Pengujian dilakukan dengan menggunakan signifkan level sebesar a. Hipotesis dalam pengujian ini adalah:

$\mathrm{H}_{0}$ : Tidak terdapat pengaruh dari variabel bebas terhadap variabel tidak bebas secara parsial

$\mathrm{H}_{\mathrm{a}}$ : Terdapat pengaruh dari variabel bebas terhadap variabel tidak bebas secara parsial

Penerimaan atau penolakan hipotesis dilakukan dengan kriteria jika nilai signifkan (Prob) $>$ a maka hipotesis ditolak (koefisien regresi tidak signifkan). Ini berarti secara parsial variabel bebas tidak mempunyai pengaruh secara signifkan terhadap variabel tidak bebas. Jika nilai signifikan $($ Prob) $\leq$ a maka hipotesis diterima (koefisien regresi signifkan). Ini berarti secara parsial variabel bebas tersebut mempunyai pengaruh yang signifkan terhadap variabel tidak bebas.

\section{HASIL DAN PEMBAHASAN}

Produksi beras di Indonesia berbeda-beda dengan kebutuhan terhadap jumlah beras yang juga berbeda satu sama lain. Perbedaan produksi beras sangat dipengaruhi oleh luas lahan baku sawah dan produktivitasnya (BPTP, 2016). Ada pun kebutuhan beras begitu dipengaruhi oleh jumlah penduduk dan besarnya rata-rata konsumsi per kapita (BPS, 2018).

Pada tahun 2018 terdapat 14 provinsi yang mengalami surplus beras sedangkan 20 provinsi lainnya mengalami defisit terhadap kebutuhan beras. Bahkan, ada provinsi yang sangat parah defisitnya, seperti Provinsi DKI Jakarta, Provinsi Riau, Provinsi Banten, dan Sumatera Utara.

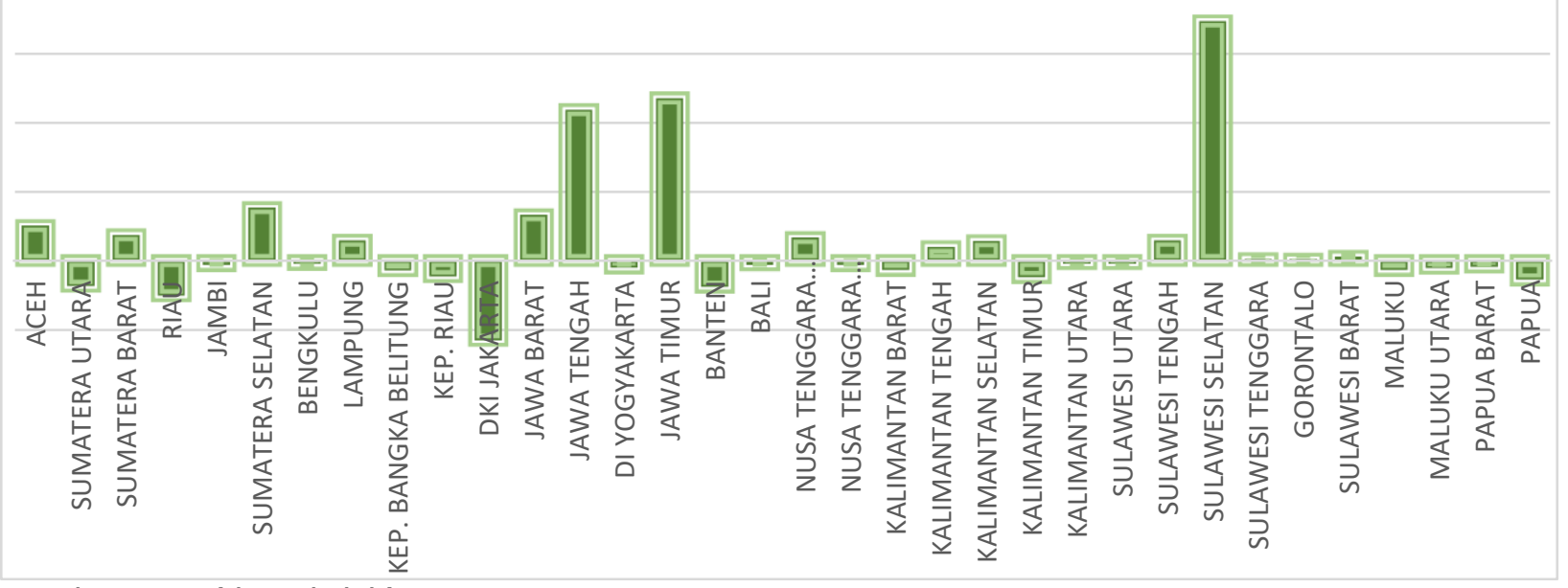

Sumber: BPS (data diolah)

Grafik 2. Surplus/Defisit Beras per Provinsi di Indonesia Tahun 2018 (ton)

Berdasarkan Grafik 1 diperoleh informasi bahwa ada beberapa provinsi yang surplus cukup besar seperti Sulawesi Selatan, Jawa Timur, dan Jawa Tengah. Sulawesi Selatan mencapai 3,47 juta ton, Jawa Timur 2,35 juta ton, dan Jawa Tengah mencapai 2,18 juta ton.

Ada pun provinsi yang berkategori cukup parah defisit kebutuhan berasnya pada tahun 2018 adalah DKI Jakarta dan Ria. Defisit DKI Jakarta mencapai 1,16 juta ton sedangkan Riau defisitnya mencapai 0,51 juta ton.

\section{Hasil Uji Normalitas}

Uji normalitas random variable (rasio kemiskinan) dengan menggunakan uji Kolmogorov Smirnov. Berdasarkan perhitungan data menggunakan $R$-studio diperoleh output $p$-value sebesar 0.205 yang berarti bahwa data sudah mengikuti distribusi normal. 


\section{Uji Heteroskedastisitas}

Uji heteroskedastisitas terhadap residual untuk menilai apakah ada ketidaksamaan varians dari residual dari semua pengamatan. Uji ini menggunakan Breusch-Pagan test. P-value yang dihasilkan sebesar 0.600 dengan tingkat signifikansi $5 \%$ dapat disimpulkan bahwa tidak terjadi heteroskedastisitas pada data.

\section{Uji Multikolinearitas}

Uji multikolinearitas dilakukan untuk memastikan apakah dalam sebuah model regresi terdapat hubungan antar-variabel bebas. Berdasarkan output $R$-Studio diperoleh VIF dari semua variabel bebas lebih kecil dari 10, maka dapat disimpulkan bahwa tidak terdapat masalah multikolinearitas antar-variabel bebas.

\section{Uji Signifikansi Parameter}

Uji parsial dilakukan untuk menguji pengaruh setiap variabel bebas (4 variabel bebas dalam model) terhadap swasembada beras. Berikut output perhitungan dengan menggunakan $R$-studio:

Tabel 2. Estimasi Variabel

\begin{tabular}{|l|l|l|l|l|}
\hline Variabel & Estimasi & $\begin{array}{l}\text { Standar } \\
\text { Eror }\end{array}$ & $\mathrm{t}$ & $\mathrm{p}$-value \\
\hline Constant & $-8.29910^{5}$ & $3.91410^{5}$ & -2.121 & 0.042 \\
\hline Harga Jagung Pipil (Rp/100 kg) & $1.16410^{-1}$ & $5.80810^{-1}$ & 0.200 & 0.843 \\
\hline $\begin{array}{l}\text { Persentase Rumah Tangga } \\
\text { Petani Padi (\%) }\end{array}$ & $1.40510^{4}$ & $5.05810^{3}$ & 2.777 & 0.010 \\
\hline $\begin{array}{l}\text { Alokasi Pupuk Urea Subsidi } \\
\text { (Ton) }\end{array}$ & 1.954 & $3.46510^{-1}$ & 5.634 & 0.000 \\
\hline Adjusted R-Squared & \multicolumn{4}{|c|}{0.577} \\
\hline
\end{tabular}

Sumber: Output pengolahan R-studio

Berdasarkan output di atas dengan signifikansi $5 \%$ dapat disimpulkan bahwa variabel persentase rumah tangga petani padi dan alokasi pupuk urea subsidi secara signifikan memengaruhi swasembada beras serta variabel harga jagung pipil tidak signifikan memengaruhi swasembada beras. Model tersebut dapat menjelaskan nilai perubahan swasembada beras sebesar $57.7 \%$. Sedangkan sisanya dapat dijelaskan oleh variabel lain yang belum tercakup ke dalam model.

\section{KESIMPULAN}

Dari 3 variabel bebas, diperoleh 2 variabel yang memengaruhi swasembada beras di Indonesia yakni variabel persentase rumah tangga petani padi dan alokasi pupuk urea subsidi, sedangkan variabel variabel persentase rumah tangga petani padi dan alokasi pupuk urea subsidi tidak signifikan memengaruhi swasembada beras. Adjusted $R$-squared sebesar 0.577 yang berarti bahwa dengan model ini variabel bebas bisa menjelaskan sebesar 57.7 persen variabel tidak bebas dan sisanya dijelaskan oleh variabel lain yang belum dimasukkan ke dalam model.

\section{DAFTAR PUSTAKA}

Badan Pusat Statistik. (2018). Ekspor Impor Beras. Jakarta: BPS.

Badan Pusat Statistik. (2018). Metode Baru Data Beras Kerangka Sampel Area (KSA). Jakarta: BPS.

Badan Pusat Statistik. (2018). Statistik Indonesia. Jakarta: BPS.

Mafor, K. I., Laoh, E. O., Dumais, J. N., \& Lolowang, T. F. (2015, February). Analisis Faktor Produksi Padi Sawah Di Desa Tompasobaru Dua Kecamatan Tompasobaru. In COCOS (Vol. 6, No. 2).

Makruf, E., Oktavia, Y., \& Putra, W. E. (2012). Faktor-Faktor Yang Mempengaruhi Produksi Padi Sawah Di Kabupaten Seluma (Studi Kasus: Produktivitas Padi Sawah di Desa Bukit Peninjauan II Kecamatan Sukaraja). 
In PROSIDING SEMINAR INOVASI TEKNOLOGI PERTANIAN SPESIFIK LOKASI MENDUKUNG EMPAT SUKSES KEMENTERIAN PERTANIAN DI PROVINSI BENGKULU (pp. 44-52).

Malian, A. H., Mardianto, S., \& Ariani, M. (2016). Faktor-faktor yang mempengaruhi produksi, konsumsi dan harga beras serta inflasi bahan makanan. Jurnal Agro Ekonomi, 22(2), 119-146.

Mubyarto, M. (1987). Pengantar Ekonomi Pertanian. Jakarta: LP3ES.

Soekartawi, S. (1993). Prinsip Dasar Ekonomi Pertanian: Teori dan Aplikasi. Jakarta: Raja Grafindo Persada.

Soekartawi, S. (1995). Pembangunan Pertanian. Jakarta: PT RAja Pratindo Persada.

Taufiq, T., Rostartina, E., \& Abukosim, A. (2009). Faktor-Faktor yang Memengaruhi Stok Beras di Sumatera Selatan. Jurnal Ekonomi Pembangunan Vol. 7 No. 1, 14-24.

Triyanto, J. (2006). Analisis produksi padi di Jawa Tengah (Doctoral dissertation, Program Pascasarjana Universitas Diponegoro). 